\title{
HART'S THE CONCEPT OF LAW AS A STUDY IN SOCIAL PHILOSOPHY
}

\author{
Eerik LAGERSPETZ*
}

Resumen:

El concepto de derecho de H. L. A. Hart es un clásico moderno de la teoría jurídica. Pero también es relevante para la filosofia moral y social. En este artículo se argumenta que las críticas de Hart hacia Austin y Bentham, asi como sus teorias sobre la naturaleza del derecho, la moral y la coerción, retoman una tradición de pensamiento iniciada por David Hume. Además, la filosofia social de Hart tiene implicaciones normativas interesantes. Este artículo se concentrará en un solo ejemplo: el concepto de libertad. A pesar de que Hart no analiza el concepto de libertad en su libro, el autor sostiene que su análisis del derecho puede ayudarnos a comprender esa noción tan altamente discutida.

\section{Palabras clave:}

Teoría jurídica, filosofia social, filosofia moral, libertad, H. L. A. Hart.

\section{Abstract:}

H. L. A. Hart's The Concept of Law is a modern classic of legal theory. However, it is also relevant to moral and social philosophy. Here, it is argued that Hart's criticism of Austin and Bentham, and his views on the nature of law, morality and coercion continue the tradition initiated by David

* Professor of Practical Philosophy. Department of Behavioural Sciences and Philosophy. 20014-University of Turku Finland. eerlag@utu.fi. 


\section{EERIK LAGERSPETZ}

Hume. Moreover, Hart's social philosophy has interesting normative implications. I shall focus on one single example: the concept of liberty. Although Hart does not analyze the concept of liberty in his book, I argue that his analysis of law may help us to understand that highly contested notion.

\section{Keywords:}

Legal Theory, Social Philosophy, Moral Philosophy, Liberty, H. L. A. Hart. 
Summary: I. Introduction. II. Two Theories of Law and Coercion. III. The Third Theory: Hume and Hart. IV. Law and Liberty. V. Bibliography.

\section{INTRODUCTION}

H. L. A. Hart's The Concept of Law (hereafter CL) is undeniably a masterpiece of the twentieth-century philosophy of law. However, in the preface of the book, Hart defines the scope of his work in wider terms:

My aim in this book has been to further the understanding of law, coercion, and morality as different but related social phenomena. Though it is primarily designed for the student of jurisprudence, I hope it may also be of use to those whose chief interests are in moral or political philosophy, or in sociology, rather than in law. ${ }^{1}$

The claim that Hart was an important social philosopher hardly requires an argument. It is enough to remind that for example, the seminal concept of fairness was first introduced to philosophical discussion by Hart, not by John Rawls as some people might think. The topic of this paper is the moral and political (or social) philosophy of Hart's best-known work. First, I try to place $C L$ into the tradition of Western socio-political thinking. Then, I briefly discuss the possible normative implications of Hart's social philosophy. I shall focus on one single example: the concept of liberty. Although Hart does not analyze the concept of liberty in $C L$, I argue that his analysis of law may help us to understand that highly contested notion.

\section{Two THEORIES OF LAW AND COERCION}

In the first chapters of $C L$, Hart target is the imperative-coercive theory (IC-theory); the view formulated by

1 Hart, H.L.A., The Concept of Law, Oxford, Great Britain, Oxford University Press, 1961, p, vii. 
Thomas Hobbes ${ }^{2}$ and first refined and canonized by Jeremy Bentham ${ }^{3}$ and then by John Austin. ${ }^{4}$ In spite of their differences, Hobbes, Bentham, and Austin all accepted the key elements of the IC-view. The key elements are the following. Law can be reduced to duties, and duties are basically commands, addressed to the subjects by their superiors. All duties are attached with sanctions which, ultimately, consist in physical coercion. The coercive element in law is required, for people are generally unwilling to perform their duties voluntarily. The reason for this is that, due to the human nature, self-interest tends to be the most powerful motive for action. Fear of coercion becomes, therefore, the most important reason for people to obey law. It is in the general interest that people perform their duties, and fear provides a self-interested motive for most people to perform them. Any society is divided into two groups: the coercers and the coerced - although the coercers may themselves be subjected to coercion, too. The "ultimate coercer" is the sovereign, the legal entity who gives commands but does not obey anyone and is, therefore, not subject to any (legal) duties. Thus, the IC-theory is not only about law, but more widely about "law, coercion, and morality as different but related social phenomena".

Although Hobbes, Bentham and Austin are historically the most important exponents of the IC-view, many of its elements are also accepted by other legal theorists. For example the Scandinavian Realists such as Karl Olivecrona, ${ }^{5}$ and some modern positivists like Kelsen -while rejecting the imperative aspects of the IC-theory and its necessary consequence, the sovereign- still seem to subscribe the 1996.

2 Hobbes, Thomas, Leviathan, Oxford, Great Britain, Oxford University Press,

3 Bentham, Jeremy, Selected Writings on Utilitarianism. Hertfordshire, Great Britain, Wordsworth Classics, 2001.

4 Austin, John, The Province of Jurisprudence Determined, Cambridge, Great Britain, Cambridge University Press, 1995.

5 Olivecrona, Karl, Law as Fact, London, Great Britain, Oxford University Press, 1939. 
theses that law is essentially coercive, and that fear is the central motive for obedience. Similarly, the contemporary Neo-Hobbesian social theorists, most notably Nobel-laureate economist James Buchanan, ${ }^{6}$ accept the main elements of the IC-theory. The Neo-Hobbesians interpret the motivational conflict between self-interest and duties in game-theoretic terms, as an instance of the Prisoner's Dilemma game. This is an important achievement, for it makes Hobbes' theory more acceptable: although individuals in the Hobbesian world are guided only by their self-interest -and therefore do not voluntarily perform their duties- a legal system which compels them to perform their duties is still mutually beneficial. The earlier, standard reading of Hobbes was more Augustinian: people are simply evil and have to be controlled. Nevertheless, even in the NeoHobbesian interpretation, fear of sanctions is the overriding motive for each individual to follow law.

Of course, the IC-view has never been universally accepted. Legal and political theorists, from Plato and Aristotle via the classical tradition of Natural Law to sociologists such Durkheim and Parsons, have emphasized the role of consensus, shared values and voluntary cooperation as necessary for the continuous existence of societies. Sociologist Talcott Parsons put the consensualist thesis into a nutshell:

A relatively established 'politically organized community' is clearly 'a moral community' to some degree, its members sharing common norms, values and culture - which is to stay that I start with a view that repudiates the idea that any political system that rests entirely on self-interest, force, or a combination of them, can be stable over a considerable period of time. ${ }^{7}$

6 Buchanan, James, The Limits of Liberty. Between Anarchy and Leviathan, Chicago, USA, Chicago University Press, 1975.

7 Parsons, Talcott, The Modern Sociological Theory, New York, USA, Free Press, 1967, p. 265. 
Neither the IC-theory nor its consensualist antithesis seems to be fully compatible with our everyday experience. The IC-theory is problematic at least for two reasons. First, a modern constitutional system is not like a tyranny. Normally and typically, the officials perform their legally defined duties and ordinary citizens, more often than not, follow the law even when there are no police officers around. The fear of sanction does not in most cases play an important role in our practical reasoning. Second, the theory faces a problem of infinite regress. If fear of sanctions were the most important motive for obeying rules, the existence of an effective constitution would be inexplicable, for the legal Leviathan could be constrained only by establishing another Leviathan that could interpret and enforce the constraints, and so on. According to John Austin both international law and constitutional law are only "positive morality" because they are not backed by sanctions. ${ }^{8}$ However, he fails to explain why this morality motivates. As Alf Ross once remarked, "ultimately there must be norms for the exercise of force which are not themselves upheld by force but are followed in fearless allegiance". 9 But if this "fearless allegiance" is possible, why suppose that only "ultimate" legal norms can have this character?

The consensualist antithesis does not fare any better. If there were a wide consensus on values in our (or any) society, we should at least be able to spell out the content of that consensus. ${ }^{10}$ (Hardin) A small community may remain stable because it is "a moral community" in the Parsonian sense. But how well does the notion fit into a modern State? Which are the values "we all" share? If we try to articulate the values shared by the citizens of the modern State, we end up to vague and abstract principles like "human life is valuable" or "democracy is good". But an agree-

8 Austin, John, op. cit., pp. 213-17.

9 Ross, Alf, On Law and Justice, London, Great Britain, Stevens, 1958, p. 57.

10 Hardin, Russell, David Hume: Moral \& Political Theorist. Oxford, Great Britain, Oxford University Press, 2007, p.125. 
ment on such principles is not sufficient to maintain a legal order. Innumerable wars and civil strives have been fought between religious groups or dynastic factions sharing the same values, at least on that level of abstraction. The contrast between individual self-interest and shared values is not crucial. (To put it crudely history shows that Christians have mainly fought against Christians, Muslims against their fellow Muslims, nationalists against the nationalists of the neighbouring country and so on).

There is, however, a third possibility, classically formulated by David Hume. ${ }^{11}$ This view recognizes that we humans are social beings whose condition is that of a mutual interdependency. Yet, it admits that our sociability is limited and particular. In one sense, this view is a compromise between the extremes. Yet, like all good middle-road solutions, it does not just provide an eclectic mixture of the competing views, but, as an Aufhebung of an intellectual conflict, it tries to explain why the previous views are both partly correct.

\section{The THIRD THEORY: Hume AND HART}

In my interpretation, the socio-political theory which forms the background of The Concept of Law is essentially Humean, although direct references to Hume in $C L$ are scanty. The part of Hart's book most directly influenced by Hume is Chapter IX, "Law and Morals", and particularly the sub-chapter entitled "The Minimum Content of Natural Law". ${ }^{12}$ Hart's argument in Chapter IX is often interpreted as a mild concession to the contemporary Natural Law theories. I think that this is a misinterpretation. The purpose of the chapter is not to find the alleged "sensible core" of the modern theories of Natural Law, but rather to lay a basis for Hart's own theory, as developed in the earlier chap-

11 Hume, David, Hume's Moral and Political Philosophy, Darien, USA, Hafner Publishing, 1970.

12 Hart, H. L. A., op.cit., pp. 189-195. 
ters of the book. Although, due to Hart's argumentative strategy in $C L$, the discussion on the "Minimum Content" appears in the last part of the work, it could equally well be the first chapter. Chapter IX is focused on those properties of human nature which, according to him, make rules indispensable elements of our social life. These properties are (1) vulnerability, (2) approximate equality, (3) limited altruism, (4) limited resources, and (5) both limited understanding and strength of will. ${ }^{13}$ Because of these limitations, cooperation between human beings tends to be fragile. In order to overcome the problems of cooperation and interaction, human beings need rules. Hart's list follows closely the list of the Conditions of Justice given by Hume. ${ }^{14}$ After Hart, similar lists have been produced, with slight modifications, by political theorists such as J. R. Lucas, ${ }^{15}$ John Rawls ${ }^{16}$ and Jeremy Waldron, ${ }^{17}$ and by moral philosophers such as G. J. Warnock ${ }^{18}$ among others.

In his main works, David Hume tried to show that our fundamental duties or obligations - most notably those related to property and to promises - are "artificial" rather than "natural". Our basic social duties are neither imprinted to our minds nor results of an original agreement. They have developed gradually as responses to the practical problems resulting from our limited nature. Their role is to help human to overcome their natural limitations in their mutual interactions.

In a sense, Hart begins where Hume finishes. Primary social obligations are -like Hume's conventions of justice-

13 Idem.

14 Hume, David, "A Treatise of Human Nature", in Hume, op. cit., pp. 57-8.

15 Lucas, J. R., The Principles of Politics, Oxford, Great Britain, Clarendon Press, 1966, pp. 5-10.

16 Rawls, John, A Theory of Justice, Oxford, Great Britain, Oxford University Press 1971, pp. 126-30.

17 Waldron, Jeremy, Law and Disagreement, Oxford, Great Britain, Oxford University Press 2001, p. 102.

18 Warnock, G. J., The Object of Morality London, Great Britain, Methuen \& Co., 1972, pp. 17-26. 
public, shared standards of conduct existing in particular communities. ${ }^{19}$ Their role is to maintain interaction among vulnerable beings whose altruism, understanding and strength of will are limited. However, when these communities become larger and internally more complex, the internal limitations of human nature tend to create new problems. First, when the rules of obligation (and the interactions regulated by them) become more complex, problems of interpretation arise. Second, the primary obligations are enforced only by the critical reactions of the members of the community. If the reactions are not coordinated - those transgressing the rules are either not punished or punished too heavily - the rules tend to lose their effectiveness. This becomes more likely when the community grows and becomes more anonymous. Third, a regime of primary rules tends to be too static. When the external circumstances change, the same social values could perhaps be realized in a better way by adopting new rules. But somebody should initiate the needed change, and the fact that the rules are going to change should be communicated to the members of society. ${ }^{20}$ For Hart, uncertainty, inefficiency and the static nature of the regime of primary rules are reasons for a community to adopt secondary rules, "rules about rules". ${ }^{21}$ These rules "provide for operations which lead not merely to physical movement or change, but to creation or variation of duties or obligations".22 Of course, even a Humean simple regime of primary rules has some secondary rules related to promising and contracts. The rules analyzed by Hart, those related to the interpretation, enforcement and change of all other rules form only an important subclass, called here as the meta-rules.

The emergence of meta-rules is an "artificiality" of second degree. If the emergence of rules described by Hume marks

19 Hart, H. L. A., op. cit., p. 89.

20 Ibidem, p. 90-1.

21 Ibidem, p. 91-6.

22 Ibidem, p. 79. 
the transition from natural sympathy to moral judgments, the emergence of meta-rules envisaged by Hart marks a further bifurcation between morality and law. Under the simple regime of primary rules, the positivist separation between law and (prevailing, accepted) morality is irrelevant. Admittedly, a community governed only by shared rules backed by social pressure may be described as a simple legal system. It is however equally plausible to say that such a community has no law, but only shared moral rules. In contrast, in a modern legal system the distinction between law and morality is clear. Although the basic rules of human conduct are still "directly" accepted, irrespective of their legal status, any modern legal system contains innumerable rules which are not generally known, or understood, or endorsed by the general population. They exist because they are enacted, interpreted, applied, and enforced by the limited sub-population of officials. The meta-rules, most notably the famous rule of recognition, exist because they are accepted as public standards of conduct within that sub-population. In a sense, the positivist thesis that law is based on social facts is itself grounded on a contingent social fact. The separation between moral standards and legal standards which is the hallmark of positivism is applicable only in modern legal systems. ${ }^{23}$

How does this view about "law, coercion, and morality" differ from the imperative-coercive view? First, the role of law is not just to constrain action. For Hume, law has essentially a coordinative role. This aspect of Hume's philosophy has been brilliantly explicated by Russell Hardin in his recent book. ${ }^{24}$ It becomes clearer when we compare it with the Neo-Hobbesian idea of law as a solution to Prisoner's Dilemmas (PDs). A Prisoner's Dilemma situation is a mixed-motive game so that although the players prefer uni-

23 For a more detailed argument, see Lagerspetz, Eerik, The Opposite Mirrors. An Essay on the Conventionalist Theory of Institutions, Kluwer, Dordrecht, The Netherlands, 1995, ch. 7.

24 Hardin, Russell, op. cit., ch. 4. 
versal cooperation to universal defection, each individual player still prefers a situation in which he or she can be a free rider while the others are dutifully doing their task. In a sense, it is misleading to say that there is a "dilemma of cooperation" in the standard Prisoner's Dilemma setting. There is no dilemma simply because if a situation really is a Prisoner's Dilemma setting, the players do not cooperate, period. Any "solution" to the problem - for example, the Hobbesian sanctions or the Durkheimian solidarity - transforms the situation into another game by adding new motivational elements not reflected in the initial description. The real dilemma is this: why and how actors who are involved in an interaction which prima facie looks like a standard PD may nevertheless be able to avoid the trap? In other words, why, in spite of all appearances, the situation in question is not really a Prisoner's Dilemma after all? The Humean answer is that the fundamental interaction problems resulting from the deficiencies of our nature are typically coordination problems, not PDs. In coordination situations, the observance of rules is self-maintaining: each player has a motive to follow a rule if the others do. Thus we have a rational motive to drive on the right (or left) side, use the standard time, the national currency, and the language generally spoken in the community we happen to reside. This does not mean that we are necessarily happy with the prevailing practices. We might prefer to drive on the other side of the road or to speak some other language. However, when all or most of the others follow a practice, we do not have a rational reason to deviate. Such rules should be analyzed as conventions rather than as contracts or commands. A very small tightly-knit community could perhaps live without conventions. For a large anonymous community, they are necessary. ${ }^{25}$ Hart adds a further non-coercive aspect to this Humean picture. The problems enumerated in $C L$, those of uncertainty, inefficiency and the static nature of primary rules can be interpreted as co-

25 Hume, David, op. cit., p. 67. 
ordination problems. This gives rise to the meta-rules, the secondary rules regulating the recognition, interpretation and enforcement of other rules. These rules are typically followed by the officials in "fearless allegiance". Hence, they are conventions rather than sanctioned commands.

One may argue that Hart's Humeanism actually goes too far. In his essay "Of the First Principles Government" Hume famously argues that because "force is always on the side of the governed", the rulers must, in order to govern, enjoy at least some voluntary support:

It is, therefore, on opinion only that government is founded, and this maxim extends to the most despotic and most military governments as well as to the most free and most popular. The soldan of Egypt or the emperor of Rome might drive his harmless subjects like brute beasts against their sentiments and inclination. But he must at least have led his mameluks or praetorian bands like men, by their opinion. ${ }^{26}$

Hence, fear cannot be sole motive for obedience in any society. This Praetorian Guard argument has been accepted as self-evident by theorists as diverse as J. R. Lucas, ${ }^{27}$ Hannah Arendt, ${ }^{28}$ José Ortega y Gasset ${ }^{29}$ and H. L. A. Hart. ${ }^{30}$ However, philosopher Gregory S. Kavka ${ }^{31}$ and sociologist Barry Barnes ${ }^{32}$ have carefully argued that the Praetorian Guard Argument is not valid. To simplify, suppose that there is a society consisting of the ruler, A, and of three subjects, B, C, and D. Suppose that B obeys A's commands

26 Hume, David, "Of the First Principles of Government", in Hume, David, op. cit., p. 307

27 Lucas, J. R., op. cit., p. 75-6.

28 Arendt, Hannah, "On Violence", in Arendt, Hannah, The Crises of the Republic, New York, USA, Harcourt, 1972, p. 140.

29 Ortega y Gasset, José, La rebelión de las masas, Madrid, Spain, Tecnos, 2003, p. 272-5

30 Hart, H. L. A., op. cit., pp. 23, 89, 196, 198.

31 Kavka, Gregory S., Hobbesian Moral and Political Philosophy, Princeton, USA, Princeton University Press, 1986, pp. 262-6.

32 Barnes, Barry, The Nature of Power, Oxford, Great Britain, Polity Press, 1988, pp. 96-100. 
only because he believes that $\mathrm{C}$ and $\mathrm{D}$ obey them voluntarily and are willing to punish him if he refuses to obey. The same is true of $\mathrm{C}$ and $\mathrm{D}$, respectively. All the subjects of A obey him only because of fear. Nevertheless, the force is on their side: by acting as a coalition, they could easily overthrow A. Only the "pluralistic ignorance" (to use a sociological term) prevents this. No loyal Praetorian Guard is needed to explain A's power over his subjects.

Still, the Praetorian Guard Argument is a plausible empirical conjecture. It is unlikely that a large modern society could, in the long run, be governed only by coercion. Hart's methodology in $C L$ is to focus on the central cases rather than to define concepts through necessary and sufficient conditions. ${ }^{33}$ This kind of approach is, I think necessary in social philosophy and, more generally, in the human sciences. (An example to illustrate this is the notion of "culture". It is certainly indispensable in these disciplines, but how to define it precisely without depriving its descriptive usefulness?) This approach would allow Hart to accept a purely coercive regime imagined by Kavka and others as a limiting case, but still insist that in the cases relevant to legal and social theory his central thesis holds:

'Sanctions' are therefore required not as the normal motive for obedience, but as a guarantee that those who would voluntarily obey shall not sacrificed to those who would not. To obey, without this, would be to risk going to the wall. Given this standing danger, what reason demands is voluntary co-operation in a coercive system. ${ }^{34}$

To clarify, while the presence of sanctions remains psychologically important, it need not be important because people fear sanctions. Rather, the mutual awareness of the presence of sanctions is important because it maintains voluntary cooperation. The possibility to rely on sanctions has two important effects. First, it diminishes uncertainty:

33 Hart, H. L. A, op. cit., pp. 3-5.

34 Ibidem, p. 193. 
the law-abiding citizen knows that if others are, for some reason or another, not willing to follow rules voluntarily, they will do so because they are afraid of sanctions. This may be essential in large and anonymous societies where people cannot only rely on personal trust based on mutual acquaintance. Second, sanctions may be important to obedience because most people's sense of justice requires that wrongdoers are punished, and one important reason for obeying the law is that it is perceived as being at least minimally just. To move from the purely coercive regime imagined by Kavka and others to the opposite limiting case: even a system in which all citizens are willing to obey the law if they believe that the others obey may need sanctions in order to eliminate the uncertainty. ${ }^{35}$

\section{LAW AND LIBERTY}

The problem with the IC-theory is not only that it cannot account meta-rules. In $C L$, Hart shows quite effectively that, at most, only a subset of ordinary laws can be conceived in terms of duties backed by sanctions. The key passages are the following:

Legal rules defining the ways in which valid contracts or wills or marriages are made do not require persons to act in certain ways whether they wish to or not. Such laws do not impose duties or obligations. Instead, they provide individuals with facilities for realizing their wishes, by conferring legal powers upon them to create, by certain specific procedures and subject to certain conditions, structures of rights and duties within the coercive framework of law.

The power thus conferred on individuals to mould their legal relations with others by contracts, wills, marriages \&c., is one of the great contributions of law to social life; and it is a feature of law obscured by representing all law as a matter of orders backed by threats. ${ }^{36}$

35 Lagerspetz, op. cit., pp. 198-207.

36 Hart, H. L. A., op. cit., pp. 27-8. 
The fundamental point in these passages (and elsewhere in $C L$ ) is that law has a constitutive role. The legal system does not just regulate, constrain and direct pre-existing forms of human behaviour. Rather it, like other complex practices, creates new types of action which did not exist before the emergence of the practice. Hume already remarked how "it is impossible for men so much as to murder each others without statutes, and maxims, and an idea of justice and honour". 37 Again, Hart continues a theme initiated by Hume:

If such rules of this distinctive kind did not exist we should lack some of the most familiar concepts of social life, since these logically presuppose the existence of such rules. Just as there could be no crimes or offences and so no murders or thefts if there were no criminal laws of the mandatory kind which do resemble order backed by threats, so there could be no buying, selling, gifts, wills, or marriages if there were no power-conferring rules. ${ }^{38}$

The non-constraining aspects of law emphasized by Hume and Hart are related to the motivational aspect discussed above: if laws have other functions besides the constraining function, fear of sanctions need not to be the most important motive for following it. Hart's criticism is, I think, a decisive one. The IC-theory cannot capture the power-conferring aspects of law. Hence, it is inadequate.

The criticism made by Hart has largely been accepted and it has become a part of the received wisdom. Legal theorists that are nowadays willing to defend the central theses of the IC-theory are few and far between. However, the influence of the IC-theory goes beyond the legal theory strictly defined. Hobbes and Bentham both tried to articulate a more general social philosophy, and some of its aspects are still at the centre of discussion. Therefore, Hart's

37 Hume, David, "Enquiry Concerning the Principles of Morals", in Hume David, op. cit., p. 206.

38 Hart, H. L. A., op. cit., p. 32. 
observation that the theory is unable to account for some important aspects of law has further consequences which are also relevant to moral and political philosophy. Here, I shall mention only one of them. In my interpretation, Hart's analysis gives a reason to rethink our notion of liberty, although Hart himself does not raise the issue directly in $C L$.

For Hobbes and Bentham, the IC-analysis of law was only a part of a more general theory about "law, coercion, and morality". The negative concept of liberty was a necessary correlate of their view of law. As Bentham wrote:

liberty then is neither more nor less than the absence of coercion. This is the genuine, original and proper sense of the word liberty. This idea is an idea purely negative. It is not anything produced by law. ${ }^{39}$

According to this view, liberty, at least politically relevant liberty, consists simply of the "silence of laws", of the absence of coercive constraints. Not only is law unable to produce liberty. Because law is essentially coercive, "every law is contrary to liberty". ${ }^{40}$ Liberty-rights imply duties, and, as we have seen, duties are considered as coercively enforceable commands. One consequence of this view is that the "sum" of liberties has to remain constant.

As against the coercion applicable by individual to individual, no liberty can be given to one man but in proportion as it is taken from another. All coercive laws, therefore (...) and in particular all laws creative of liberty, are as far as they go, abrogative of liberty. ${ }^{41}$

39 Bentham's unpublished manuscripts. Quoted after Long, Douglas G., Bentham on Liberty, Toronto, Canada, Universityof, Toronto Press, 1977, p. 74.

40 Bentham, Jeremy, "Principles of the Civil Code. Part I - Objects of the Civil Law", in Bentham, Jeremy, Selected Writings on Utilitarianism, Hertsfordshire, Great Britain, Wordsworth Classics, 2001, p. 314.

41 Bentham, Jeremy, "Anarchical Fallacies", in Bentham, Jeremy, Selected Writings on Utilitarianism, Hertsfordshire, Great Britain, Wordsworth Classics, 2001, p. 401. 
Hobbes and Bentham's "social topology" is very simple. Individuals are like freely-moving bodies. Laws, like physical barriers, limit their movement. The proper task of law is to prevent these bodies to collide by building walls around them. The liberty of an individual is the space within the surrounding walls. The requirement of maximal liberty means that the cells should be as large as possible. The requirement of equal liberty means that all the cells should be of equal size.

The idea that politically relevant liberty is simply the absence of coercive restrictions has been more persistent than the correlative idea that law is simply a set of such restrictions. Thus in his famous inaugural lecture ${ }^{42}$ Sir Isaiah Berlin adopted the Benthamite notion of liberty and declared it a part of the liberal credo. Numerous commentators have accepted the basic claims put forth by Berlin or implied by his essay: the negative concept of liberty is the one which corresponds with our untutored intuitions or with ordinary usage of the word, and it alone is compatible with liberalism. Thus, those who have criticized Berlin's "negative liberty" - for example, C. B. Macpherson, ${ }^{43}$ Charles Taylor ${ }^{44}$ or Philip Pettit ${ }^{45}$ - have usually portrayed themselves as critics of the liberal view. In this context, I cannot assess these criticisms, but I just want to point out that neither Berlin nor his critics have paid attention to the close relationship between Hobbes's and Bentham's notions of liberty and their notion of law. As far as I know, Berlin did not accept the IC-theory of law, nor have his critics claimed that he, as a consequent liberal, should have ac-

42 Berlin, Isaiah, "Two Concepts of Liberty", in Berlin, Isaiah Four Essays on Liberty, Oxford, Great Britain, Oxford University Press, 1969, pp. 118-172.

43 MacPherson, C. B., "Berlin's Division of Liberty", in MacPherson, C. B., Democratic Theory. Essays in retrival, Oxford, Great Britain, Oxford University Press, 1975, pp. 95-117.

44 Taylor, Charles, "What's Wrong with Negative Liberty", in Taylor, Philosophy and the Human Sciences. Philosophical Papers 2, Cambridge, Great Britain, Cambridge University Press, 1985, pp. 211-229.

45 Pettit, Philip, "Freedom with Honour: A Republican Ideal", Social Research 64, 1997, pp. 52-76. 
cepted it. There is nothing specifically liberal in the IC-view; indeed, many liberals of different persuasions, from Hayek to Dworkin, have considered it a deeply illiberal view. Because the negative notion of liberty follows from the IC-theory rather than the other way round, it is possible to reject the latter and nevertheless stick to the former. However, if the negative notion of liberty is actually a sort of by-product of one once widely accepted but rather implausible and nowadays rejected theory of law, the connection between liberalism and the negative notion is far less obvious than both Berlin and his critics tend to think. I shall argue that the negative concept of liberty is actually insufficient even for liberal purposes. Indeed, without the IC-theory there seems to be very few reasons to accept the negative concept of liberty.

To make the matter more clear, consider a person who is put under guardianship. He is unable to make valid contracts, to make will, to vote, or marry. This does not mean that he is prevented from doing all these things by coercive restraints, or that he is subjected to any specific duties. He may well draft and sign texts entitled as "My Last Will and Testament" or "A Contract of Sales" without being subjected to any coercive measures. He may raise his hand when votes are counted, he is allowed to hand a credit card to a bank clerk, or to say "I do" at the presence of a minister. He may be free to perform the same sets of physical movements as his fellow citizens. As a physical body, he is able to move as freely as other similar bodies. The difference is that his movements do not have their normal legally defined meaning. They do not count. The courts do not enforce "the will" or "the contracts" signed by him. When he raises his hand in the meeting, it is not counted. The bank clerk refuses to give him any money. And so on. It seems plausible to say that the ward is less free than the rest of us. He is less free because he does not possess certain powers which can be conferred to him only by legal rules. To conceptualize the ward's legal inability to do certain things 
as unfreedom is, I think, fully in accordance with the normal use of the word "freedom". Berlin and his followers stress that inabilities do not limit our freedom. This is prima facie a plausible claim. For example, if I am free to walk on public pathway, my freedom is not diminished if I during my walk break my leg and become unable to continue. But a legal inability is an inability of a different kind. It, unlike my injury, is an intended result of the action (or inaction) of the power-holders and can be removed just by amending the rules.

If this argument is correct, important aspects of our politically relevant liberty - the liberty to make contracts, marry etc. - is, contra Bentham, produced by law. Laws which confer us powers to do these and similar things need not to be "abrogative" to anyone's liberty. Liberty - that is, the kind of liberty which should interest even liberals - is not a purely zero-sum notion, and it cannot be defined merely as "the silence of laws". Certainly, the freedom to make contracts, or otherwise establish mutually beneficial relations with other people is paradigmatically a liberal issue. If this freedom cannot be defined in terms of negative liberty, there seems to be no reason to claim that it is the liberal notion.

I am interested in this argument mainly because it is so simple. Unlike most criticisms of the negative concept of liberty, it does not presuppose any particular theory of human nature, or morality, or society. It accepts a background supposition made by Hobbes and Bentham: the concept of (politically relevant) liberty is tied to the concept of law. There is, for example, no need to postulate the "higher" and "lower" selves, a postulate accepted by the Idealists and criticized by Berlin. Nevertheless, the argument has interesting further implications. As Hart says in $C L$, the role of law in our lives is far more complicated than that suggested by the IC-view. Bentham though that the only connection between liberty and law is that law can make liberties more secure, by protecting us from the intrusions 
of others. This is one link between liberty and law. But our example reveals another connection. On the one hand, law can make us freer by enabling us to do things which cannot be done outside the legal context. It can also extend the "total sum" of our liberties by giving us new legal abilities. On the other hand, law can also diminish our liberty without constraining us by depriving some of our legally defined powers. The topology of the (politically relevant) freedom is much more complex than Hobbes and Bentham thought. If our legally defined powers are a part of our liberty, it is not clear what maximal liberty might mean. This might be considered as an argument against the inclusion of legally defined abilities. But it may also be considered as a limitation of our ability to compare the amounts of freedom across various legal systems.

The purpose of this brief exposition was to show that, after fifty years, H. L. A. Hart's The Concept of Law is still worth of reading, not only by those who are interested in the philosophy of law in the narrow sense, but also, to quote Hart once again, by all "those whose chief interests are in moral or political philosophy, or in sociology, rather than in law".

\section{BIBLIOGRAPHY}

ARENDT, Hannah, The Crises of the Republic, New York, USA, Harcourt, 1972.

AUSTIN, John, The Province of Jurisprudence Determined, Cambridge, Great Britain, Cambridge University Press, 1995.

BARNES, Barry, The Nature of Power, Oxford, Great Britain, Polity Press, 1988.

BENTHAM, Jeremy, Selected Writings on Utilitarianism. Hertfordshire, Great Britain, Wordsworth Classics, 2001.

, "Principles of the Civil Code. Part I - Objects of the Civil Law", in Bentham, Jeremy, Selected Writings on Utilita- 
rianism, Hertsfordshire, Great Britain, Wordsworth Classics, 2001.

_-, "Anarchical Fallacies", in BENTHAM, Jeremy, Selected Writings on Utilitarianism, Hertsfordshire, Great Britain, Wordsworth Classics, 2001.

BERLIN, Isaiah, "Two Concepts of Liberty", in BERLIN, Isaiah Four Essays on Liberty. Oxford, Great Britain, Oxford University Press, 1969.

Buchanan, James, The Limits of Liberty. Between Anarchy and Leviathan, Chicago, USA, Chicago University Press, 1975.

HARDIN, Russell, David Hume: Moral \& Political Theorist. Oxford, Great Britain, Oxford University Press, 2007.

HART, H. L. A., The Concept of Law, Oxford, Great Britain, Oxford University Press, 1961.

HobBes, Thomas, Leviathan, Oxford, Great Britain, Oxford University Press, 1996.

Hume, David, Hume's Moral and Political Philosophy, Darien, USA, Hafner Publishing Co., 1970.

KAVKA, Gregory S., Hobbesian Moral and Political Philosophy, Princeton, USA, Princeton University Press, 1986.

LAGERSPETZ, Eerik, The Opposite Mirrors. An Essay on the Conventionalist Theory of Institutions, Dordrecht, The Netherlands, Kluwer, 1995.

LonG, Douglas G., Bentham on Liberty, Toronto, Canada, University of Toronto Press, 1977.

LuCAS, J. R., The Principles of Politics, Oxford, Great Britain, Clarendon Press, 1966

MACPHERSON, C. B., "Berlin's Division of Liberty", in MACPHERSOn, C. B., Democratic Theory. Essays in retrival, Oxford, Great Britain, Oxford University Press, 1975. 
OliveCRonA, Karl, Law as Fact, London, Great Britain, Oxford University Press, 1939.

ORTEGA y GASSET, José, La rebelión de las masas, Madrid, Spain, Tecnos, 2003.

PARSOns, Talcott, The Modern Sociological Theory, New York, USA, Free Press, 1967.

PETTIT, Philip, "Freedom with Honour: A Republican Ideal", Social Research 64, 1997.

RAWLS, John, A Theory of Justice, Oxford, Great Britain, Oxford University Press 1971.

Ross, Alf, On Law and Justice, London, Great Britain, Stevens, 1958.

TAYLOR Charles, "What's Wrong with Negative Liberty", in TAYLOR, Philosophy and the Human Sciences. Philosophical Papers 2, Cambridge, Great Britain, Cambridge University Press, 1985.

WALDRON, Jeremy, Law and Disagreement, Oxford, Great Britain, Oxford University Press, 2001.

WARNOCK, G. J., The Object of Morality London, Great Britain, Methuen \& Co., 1972. 